ORIGINAL ARTICLE

\title{
Entitlement and organizational behaviors: the moderating role of narcissism
}

\author{
Agata Szalkowska ${ }^{1 \cdot A, B, D, E, F}$, Magdalena Żemojtel-Piotrowska ${ }^{1 \cdot A, C, D, E, F}$, Amanda Clinton ${ }^{2 \cdot D, E}$ \\ 1: Institute of Psychology, University of Gdansk, Gdansk, Poland \\ 2: Institute of Psychology, University of Puerto Rico, Puerto Rico
}

BACKGROUND

The purpose of this study was to investigate the relationship between psychological entitlement (active, passive, and revenge), narcissism and two types of organizational behaviors in employees. Interactions between narcissism and psychological entitlement as predictors of organizational citizenship behaviors (OCB) and counterproductive work behaviors (CWB) were explored. Predictors were analyzed in an effort to determine whether psychological entitlement plays a more destructive role among narcissistic employees than among non-narcissistic ones and whether the effects of narcissism on OCB and CWB are mediated by entitlement.

\section{PARTICIPANTS AND PROCEDURE}

Data were obtained from 100 employees (34\% men) aged 22 to 59 years $(M=37.00, S D=9.30)$ from public and private companies. Participants were asked to complete the Organizational Citizenship Behavior Scale (OCBS), the Counterproductive Organizational Behaviors Scale (COBS), the Entitlement Questionnaire, and the Narcissistic Personality Inventory (NPI).
RESULTS

Positive aspects of entitlement were positively associated with OCB only among narcissistic employees, and active entitlement mediated the effects of narcissism on CWB. Active entitlement was negatively related to CWB. Negative aspects of entitlement were negatively related to $\mathrm{OCB}$ and unrelated to CWB.

\section{CONCLUSIONS}

This study provides evidence for positive (healthy) aspects of entitlement for organizations. The unexpected interaction between narcissism and entitlement in predicting higher levels of OCB suggests that among narcissistic employees, healthy aspects of entitlement are desirable and profitable for an organization. Psychological entitlement was observed to be an important predictor of organizational behaviors beyond narcissism itself.

\section{KEY WORDS}

organizational citizenship behaviors (OCB); counterproductive organizational behaviors (CWB); entitlement; narcissism

CORRESPONDING AUtHOR - Magdalena Żemojtel-Piotrowska, Ph.D., Institute of Psychology, University of Gdansk,

4 Bażyńskiego Str., 80-952 Gdansk, Poland, e-mail: psymzp@ug.edu.pl

Authors' Contribution - A: Study design · B: Data collection · C: Statistical analysis · D: Data interpretation ·

E: Manuscript preparation · F: Literature search · G: Funds collection

TO CITE THIS ARTICLE - Szalkowska, A., Żemojtel-Piotrowska, M., \& Clinton, A. (2015). Entitlement and organizational

behaviors: the moderating role of narcissism. Current Issues in Personality Psychology, 3(4), $230-241$.

RECEIVED 21.07.2015 - REVIEWED 04.09.2015 · ACCEPTED 18.09.2015 · PUBLISHED 03.10.2015 


\section{BACKGROUND}

Organizational behaviors are often analyzed in the work context due to their fundamental practical importance and relation to positive or negative attitudes toward work (Cole, 1995; Spector, 2011). For this reason, searching for possible conditions and predictors of organizational behaviors has received significant attention (Blakely, Andrews, \& Moorman, 2005; Spector, 2011). Among these behaviors one can distinguish positive, profitable for organizations, i.e. organizational citizenship behaviors (OCB, see Organ, 1997; Podsakoff, Mackenzie, Paine, \& Bachrach, 2000) and dysfunctional, costly behaviors, i.e. counterproductive work behaviors (CWB, Fox, Spector, \& Milles, 2001; Spector, 2011).

A good example of research identifying predictors of organizational behaviors is work by Spector (2011) on antecedents of counterproductive behaviors (CWB). He proposed a model integrating personality factors with emotional and motivational variables in predicting levels of CWB. A focus on dispositional, motivational and emotional antecedents of organizational citizenship behaviors is also present in the field (Miles, Borman, Spector, \& Fox, 2002; Spector \& Fox, 2002).

In the current paper, we propose including entitlement as a predictor of citizenship and counterproductive organizational behaviors in addition to its typical conceptualization, which is strongly embedded in the narcissistic approach. Although narcissism itself is often examined in the work context (see Campbell, Hoffman, Campbell, \& Marchisio, 2011 for review), it is rarely linked with psychological entitlement as a predictor of organizational behaviors. Thus our approach is unique in relation to studies conducted in general personality and social psychology (e.g. Ackerman \& Donnellan, 2013; Campbell, Bonacci, Shelton, Exline, \& Bushman, 2004; Exline \& Zell, 2009; Twenge \& Campbell, 2009). Moreover, prior studies focused largely on negative aspects of entitlement (Fisk, 2010; Harvey \& Martinko, 2009). However, entitlement is a multidimensional phenomenon and is not limited to negative and dysfunctional aspects (Lessard, Greenberger, Chen, \& Farruggia, 2011; Rothman, 2012; Żemojtel-Piotrowska, Piotrowski, \& Clinton, 2015b). In the multidimensional approach, entitlement is often subcategorized as non-pathological (in effect, functional) and dysfunctional (e.g. Fisk, 2010; Rothman, 2012). Furthermore, in the current study we focus both on the counterproductive behaviors that are harmful and costly for an organization and on OCB that support and are profitable for a workplace. We examine the interplay between entitlement and narcissism as predictors of both types of organizational behaviors, in an effort to determine which aspects of entitlement, defined as a multidimensional phenomenon (Żemojtel-Piotrowska et al., 2015a), enhance or inhibit CWB and OCB among narcissistic and non-narcissistic individuals and whether relationships between narcissism and organizational behaviors are mediated by entitlement. This last research question aims to supplement prior research through the inclusion of more comprehensive conceptualization of entitlement attitudes that are both related and unrelated to narcissism and addressed as simultaneous (along with narcissism) predictors of OCB and CWB.

\section{ORGANIZATIONAL BEHAVIORS: CITIZENSHIP BEHAVIORS AND COUNTERPRODUCTIVE BEHAVIORS}

Organizational behaviors are defined as individual behaviors within work teams (Cole, 1995). As mentioned above, these include behaviors that are both positive and profitable for an organization, such as organizational citizenship behaviors (Organ, 1988; Podsakoff et al., 2000), and dysfunctional behaviors, defined as counterproductive organizational or work behaviors (Fox, Spector, Goh, Bruursema, \& Kessler, 2012; Fox et al., 2001). Citizenship behaviors increase work efficacy and are voluntarily undertaken by individuals in the workplace; they increase work efficacy and they are not a result of formal reward systems, nor are they formal duties of employees (Organ, 1988). According to Podsakoff et al. (2000), if an individual does not engage in negative behaviors, it could be also regarded as a citizenship behavior. For this reason, counterproductive and citizenship behaviors logically contradict each other. Counterproductive behaviors naturally are also not included in the formal duties of workers and they are performed voluntarily (Fox et al., 2012). These behaviors negatively influence work efficacy, as they bring negative outcomes both for the organization itself (e.g. by damaging the company's reputation) and for co-workers (e.g., rumors or conflicts; Podsakoff, Whiting, Podsakoff, \& Blume, 2009).

Both OCB and CWB are conditioned by emotional reactions and by personality traits (Miles et al., 2002). Organizational citizenship behaviors is a result of positive affectivity, high control, empathy and helpfulness, while CWB is a result of negative affectivity, neuroticism and low control (Spector \& Fox, 2002). Spector and Fox (2002) assume that the dispositional factors which influence both locus of control and affectivity are important predictors of CWB and OCB levels (see also Miles et al., 2002). In the current study we argue that one such dispositional factor could be entitlement.

\section{PSYCHOLOGICAL ENTITLEMENT IN THE WORK CONTEXT}

Former research on entitlement often links it to narcissism. Despite differences between psychological 
entitlement, defined by Campbell et al. (2004) as a pervasive sense that the individual deserves more and he/she is entitled to more than others, and narcissistic entitlement, defined as unjustified expectation for special treatment (Raskin \& Terry, 1988), these differences are not essential (see Ackerman \& Donnellan, 2013). Specifically, psychological entitlement is related to higher self-esteem and grandiose narcissism, whereas narcissistic entitlement is related to lower self-esteem and vulnerable narcissism (Ackerman \& Donnellan, 2013). There are also some differences in personal correlates of both phenomena (Pryor, Miller, \& Gaughan, 2008).

In recent research, types of entitlement were distinguished as incorporating adaptive and healthy attitudes, resembling assertiveness, and excessive entitlement, which is problematic and dysfunctional (Fisk, 2010). Tomlinson (2013) further points to the distinction between entitlement as a personal trait versus a set of beliefs, which are related to formulating demands and based on personality.

Generally, in the work context, entitlement is regarded both as the expectation of reward in exchange for one's effort (Feather, 2003; Desmarais \& Curtis, 1997; Major, McFarlin, \& Gagnon, 1984; Pelham \& Hetts, 2001), which is the most typical conceptualization in social psychology, and as an excessive demand toward one's employer which is not based on actual effort (Fisk, 2010; Harvey \& Martinko, 2009, see also Tomlinson, 2013 for review), which is the most typical conceptualization in personality psychology.

Harvey and Martinko (2009) analyzed how psychological entitlement is related to lower satisfaction with work and higher levels of conflict with supervisors. They argued that the negative impact of psychological entitlement is conditioned by dysfunctional attribution processes. That is, employees with high levels of entitlement tend to formulate demands on the basis of being a member of a team, not on actual effort (see also Naumann, Minsky, \& Sturmann, 2002).

Excessive entitlement and narcissism are linked to counterproductive organizational behaviors (Penney \& Spector, 2002). In particular, they are both blamed for unrealistic financial expectations and unrelated to actual effort or input (Fisk, 2010; Tomlinson, 2013). Entitlement influences dissatisfaction with work via the perception of injustice in the organization (Byrne, Miller, \& Pits, 2010), and it could increase the number of counterproductive behaviors. Narcissism in the work context is typically conceptualized as overt or grandiose narcissism based on inflated self-esteem (see Miller \& Campbell, 2008).

In general, recent research tends to assume that entitlement has a negative impact on functioning in the work context. In a non-work context, psychological entitlement is typically regarded as a negative or problematic personal trait due to its association with narcissism, as well (Fisk, 2010; Harvey \& Martinko, 2009, see also Campbell et al., 2004). This negative conceptualization of entitlement can lead to oversimplification of explanations of its relationship with organizational behaviors. For instance, according to entitlement concepts put forth by Huseman, Hatfield and Miles (1987) in their refinement of Adams (1963) equity theory (see also Blakely et al., 2005), people prefer reward allocations based on equity rules. Individuals who are oversensitive to underpayment inequity are labeled as entitled. These entitled individuals believe that they are deprived and receive less than they should receive. This belief leads to lower satisfaction with work, which in turn could decrease levels of positive organizational behaviors while increasing negative ones (Byrne et al., 2010; Huseman et al., 1987).

\section{THREE-DIMENSIONAL MODEL OF ENTITLEMENT ATTITUDES}

Due to the complexity of entitlement, which is recognized by scholars in the field (see Naumann, Minsky, \& Sturman, 2002; Tomlinson, 2013 for review), we assume three dimensions of entitlement: active, passive, and revenge (Żemojtel-Piotrowska et al., 2013; Żemojtel-Piotrowska et al., 2015b). This model allows for integration of different aspects of entitlement notably social and personality psychology - as per current conceptualizations in the scientific literature. A multi-dimensional approach to entitlement is particularly important in professional contexts where entitlement is assumed to have a negative impact. This is the case in spite of the fact that formulating expectations toward others could be potentially profitable not only for the individual but also for the organization.

Active entitlement is defined as a tendency to protect one's own interest and actively pursue personal goals. It is expressed in beliefs such as, "I deserve the best" and "I often demand to be treated properly". It correlates with higher self-esteem and internal locus of control (Piotrowski \& Żemojtel-Piotrowska, 2009), and it is positively related to agency (Żemojtel-Piotrowska et al., 2015b). Passive entitlement is based on the belief that other people and institutions have obligations toward the individual and that they are responsible for satisfying an individual's needs. Passive entitlement is positively related to lower self-esteem, an external locus of control (Piotrowski \& ŻemojtelPiotrowska, 2009) and communion (Żemojtel-Piotrowska et al., 2015b). Revenge entitlement is defined as protection of self-interest in instances where it is violated and an insistence on revenge in the case of sustained insults. It is expressed in beliefs such as, "I remember harm inflicted on me for a long time" and, "I have difficulties forgiving sustained insults". Revenge entitlement is unrelated to self-esteem and locus of control (Piotrowski \& Żemojtel-Piotrowska, 2009), and positively related to unmitigated agency 
(Żemojtel-Piotrowska et al., 2015b). Active and revenge entitlement are positively related to psychological entitlement (Żemojtel-Piotrowska et al., 2015a), and they seems to incorporate adaptive (active) and dysfunctional (revenge) aspects of psychological entitlement. Passive entitlement is different from active and revenge entitlement in that there is an overlapping communal aspect of entitlement that seems to be more similar to a sense of entitlement as observed in the social justice or sociology literature. This form of entitlement is broadly examined within the Central-European cultural context (Klicperova, Feierebend, \& Hoffsteter, 1997; Koralewicz \& Ziolkowski, 1991), whereas psychological entitlement is more popular in research conducted in English speaking countries.

\section{THE CURRENT RESEARCH}

Since the three dimensional model of entitlement covers different aspects of entitlement, i.e. adaptive (active and passive entitlement) and dysfunctional (revenge entitlement), and assumes different motivations behind each of the three forms of entitlement, i.e. active (active and revenge entitlement) and passive (passive entitlement) (Żemojtel-Piotrowska et al., 2015a, 2015b), it is possible to precisely predict the relationship between entitlement and organizational behaviors. Furthermore, as these three dimensions have been examined in terms of their relationships with basic personality traits (Żemojtel-Piotrowska \& Piotrowski, 2011), subjective well-being (Żemojtel-Piotrowska et al., 2013), and locus of control (Piotrowski \& Żemojtel-Piotrowska, 2009), such defined entitlement is promising in terms of Spector and Fox's (2002) model of organizational behaviors.

Active entitlement as an adaptive, proactive form of entitlement that is positively related to subjective well-being (Żemojtel-Piotrowska et al., 2013) should also be positively related to citizenship behaviors, yet unrelated or even negatively related to counterproductive ones, since it is based on overt pursuit of personal goals. Active entitlement is clearly related to entitlement as reported in studies on social justice, especially expectations for reward formulated on the basis of one's own effort (Major et al., 1984; Pelham $\&$ Hetts, 2001).

Passive entitlement is based on a collectivistic vision of the social world (Piotrowski \& Żemojtel-Piotrowska, 2009) and communion (Żemojtel-Piotrowska et al., 2015a), unrelated to subjective well-being (Żemojtel-Piotrowska et al., 2013) and negatively related to unhindered agency (Żemojtel-Piotrowska et al., 2015a). Given the negative relation between passive entitlement and agency, it is possible that this form of entitlement is unrelated to organizational citizenship behaviors, since they assume some effort, and nega- tively related to counterproductive organizational behaviors, since they require effort and they are based on negative attitudes toward the organization.

Revenge entitlement is assumed to be negatively correlated with organizational citizenship behaviors and positively with counterproductive ones, as it is similar to revengefulness. This form of entitlement covers negative aspects of psychological entitlement (Żemojtel-Piotrowska et al., 2015a) and it is related positively to negative affectivity (Żemojtel-Piotrowska et al., 2015c). However, it is not clear if revenge entitlement is related to grandiose narcissism, since a relationship has been identified in earlier research but the findings remain to be confirmed (Piotrowski \& Żemojtel-Piotrowska, 2009) and in some studies - they are not confirmed (Żemojtel-Piotrowska et al., 2015a). For this reason, it is possible that revenge entitlement could increase counterproductive work behaviors.

Active, passive and revenge entitlement could interact with narcissism as a personal trait, as they are rather a stable set of convictions or beliefs rather than personality traits, like psychological entitlement (Campbell et al., 2004) or narcissistic entitlement (Bishop \& Lane, 2002; Rothman, 2012). Grandiose narcissism could be regarded as a moderating variable in predicting the relationship between entitlement attitudes and organizational behaviors, as entitlement could have different functions among narcissistic and non-narcissistic workers. However, active entitlement could also be a mediator in the relationship between narcissism and organizational behaviors. We expect such mediation only for active entitlement, as in former studies revenge entitlement and passive entitlement were unrelated to narcissism.

Specifically, we hypothesize that highly narcissistic individuals differ from non-narcissistic individuals in terms of the relationships between entitlement and organizational behaviors. Narcissism is posited to be negatively associated with citizenship organizational behaviors; however, some studies suggest that narcissistic individuals may engage in organizational citizenship behaviors as a function of attempts to manage the impression they make in the workplace (see Campbell et al., 2011 for review). Conversely, narcissism is positively related to counterproductive organizational behaviors (see Campbell et al., 2011), since highly narcissistic individuals tend to demonstrate exaggerated and excessive forms of entitlement. Moreover, they tend to be vindictive in reaction to perceived injustice (Spector, 2011), for which reason we posit that negative aspects of entitlement should demonstrate a stronger positive relationship with counterproductive behaviors among narcissistic individuals than among non-narcissistic ones. We do not predict a relationship between organizational behaviors and positive aspects of entitlement as a function of narcissism.

Finally, we explore possible mediation effects of the interrelationship between narcissism and organ- 
izational behaviors via entitlement. In prior studies, narcissism has been shown to be positively related to active entitlement (Piotrowski \& Żemojtel-Piotrowska, 2009; Żemojtel-Piotrowska et al., 2015a). For this reason, we focus only on the possible mediation of the relationship between narcissism and organizational behaviors by active entitlement. Since active entitlement is posited to be positively related to organizational citizenship behaviors, we expect that it could inhibit negative effects of narcissism on organizational behaviors, as narcissists could be less prone to engage in negative reactions when they prefer to achieve their goals in a more direct way (see Campbell et al., 2011).

\section{PARTICIPANTS AND PROCEDURE}

One hundred working adults (34\% men), with an age range from 22 to 59 years $(M=37.00, S D=9.30)$ participated in this study. Participants were employed as office workers. Seventy-two percent worked in the public sector and $28 \%$ in the private sector. Ninety percent of participants had a university education (MA or BA), $8 \%$ had a secondary school education, $1 \%$ had completed elementary professional training (i.e. professional elementary school preparing qualified workers, such as carpenters or plumbers), and $1 \%$ elementary school education. The length of time of their current employment ranged from 1 month to 31 years $(M=11.49$ years, $S D=9.05)$.

Participants were recruited to take part in the online survey using the snow-ball method, i.e. they were asked to invite other employees (their family members, friends, or colleagues) who might be interested in taking part in the current research. They were informed about the aim and procedure of the study (e.g. anonymity, possibility of withdrawal from the study). Information about the study, including a link to the survey, was posted on forums for different professional groups. Respondents did not receive any remuneration for taking part in the survey.

\section{MEASURES}

Participants were asked to complete the Organizational Citizenship Behavior Scale (OCBS), the Counterproductive Organizational Behaviors Scale (COBS), the Entitlement Questionnaire, and the Narcissistic Personality Inventory (NPI). Methods were presented in random order.

Citizenship Organizational Behaviors. Citizenship organizational behaviors were assessed by the Citizenship Organizational Behaviors Questionnaire (COBQ) (Czarnota-Bojarska, 2011). The COBQ consists of 33 items, and is based on the Podsakoff et al. (2000) model of actions considered helping behaviors, sportsmanship, organizational loyalty, organizational compliance, individual initiative, civic virtue, and self-development. Examples of statements include I fulfill others' duties when they are absent, and, When I do my work assignments I do my best, and they refer to organizationally desired behaviors. Participants indicate to what extent particular behavior is typical for them (from 0 - completely untypical to 5 - very typical) (Czarnota-Bojarska, 2011). Reliability of the COBQ in current research is .92 (Cronbach's $\alpha$ ).

Counterproductive Organizational Behaviors. To assess the level of counterproductive organizational behaviors we used the Counterproductive Organizational Behaviors Scale (COBS, Czarnota-Bojarska, 2012). This scale consists of 33 statements describing counterproductive behaviors (e.g. Use of company equipment for private purposes; Prolongation of breaks in work). Participants indicate the frequency with which they engage in these behaviors on a five-point Likert scale (from 1 - never to 5 - very often). The reliability of the COBS is .96 (Cronbach's $\alpha$ ).

Entitlement Attitudes. To assess the level of entitlement attitudes, the Entitlement Questionnaire (Piotrowski \& Żemojtel-Piotrowska, 2009) was used. This scale serves as a measure of active, passive, and revenge entitlement as defined earlier in the article. It consists of 36 items, 12 per factor (e.g. If I receive less than I deserve I speak openly about it; It is a duty of the state to provide a proper standard of living to all citizens; I do not forget sustained insults). Participants answer on a scale of options ranging from 1 (definitely disagree) to 6 (definitely agree). The Entitlement Questionnaire has proven reliability - Cronbach's $\alpha$ is .86 for active entitlement, .86 for passive entitlement and .84 for revenge entitlement, respectively (Piotrowski \& Żemojtel-Piotrowska, 2009) - and validity, as shown by correlations with other measures of entitlement (Żemojtel-Piotrowska et al., 2015a), agency and communion (Żemojtel-Piotrowska et al., 2015b) and self-enhancement values (Żemojtel-Piotrowska, Piotrowski, \& Baran, 2011).

Narcissism. To assess narcissism levels, Raskin and Terry's (1988, Polish version Bazińska \& DratRuszczak, 2000) Narcissistic Personality Inventory (NPI) was used. The NPI serves as a measure of grandiose, agentic narcissism and is one of the most broadly used scales for assessment of this phenomenon, including in the work context. The scale has proven reliability and validity in the Polish context (Bazińska \& Drat-Ruszczak, 2000). Sample items are: I like to look at my body; I find it easy to manipulate people. Participants answered questions on a 5-point Likert scale, from 1 (it's not me) to 5 (it's me). Only the general mean score is calculated in the research, and, using this score, the overall reliability of scale has been measured as reliable at the .95 level (Cronbach's $\alpha$ ). We did not calculate subscales of NPI as the main aim of our study was to examine grandiose narcissism as 
a moderating variable in the relationship between organizational behaviors and entitlement.

Demographics. Participants were asked to indicate their gender, age (in years), education, and length of employment in their current workplace (in years and months).

\section{RESULTS}

\section{CORRELATIONAL ANALYSES}

Zero-order correlations of entitlement attitudes to narcissism and organizational behaviors are reported in Table 1. Congruent with predictions, active and passive entitlement correlated positively with citizenship behaviors and negatively with counterproductive ones, while revenge entitlement correlated negatively with citizenship behaviors, but, contrary to predictions, it was unrelated to counterproductive organizational behaviors. Active and passive entitlement correlated in opposite directions in comparison to narcissism, which was, congruent to former results, positively related to counterproductive behaviors.

\section{HIERARCHICAL REGRESSION ANALYSES}

In subsequent analyses, entitlement attitudes were regarded as predictors of organizational behaviors. To examine the relative importance of narcissism and entitlement attitudes in explaining organizational behaviors (both desirable and undesirable) the mean score for NPI was introduced in the first step. Entitlement attitudes were introduced in subsequent steps. In the final step, interactions between narcissism and each form of entitlement were introduced. Age, gender, education and years in one's current position were controlled in all of the analyses. Hierarchical regressions analyses allowed us to examine both a possible mediating and a possible moderating role for narcissism in the relationship between entitlement attitudes and organizational behaviors. Results of hierarchical regression analyses for citizen- ship organizational behaviors and counterproductive behaviors are presented in Table 2 .

Entitlement attitudes and organizational behaviors. Entitlement attitudes allowed us to predict both citizenship and counterproductive organizational behaviors over narcissism. Including three forms of entitlement substantially increased the percentage of explained variance of organizational behaviors. Interestingly, narcissism itself did not hold predictive power for positive organizational behavior, indicating that it is related only to actions that are harmful for organizations. Active entitlement was positively related to citizenship behavior $(\beta=.27)$ and negatively to counterproductive behavior $(\beta=-.34, p<.001)$, indicating that this form of entitlement is beneficial for organizations. Revenge entitlement was uniquely related negatively to citizenship behaviors $(\beta=-.25)$, but was unrelated to negative actions. The differences between revenge entitlement and narcissism in their relationship to organizational behaviors suggest that revenge entitlement is probably less dysfunctional for an organization than narcissism, particularly since revenge entitlement is only related to an absence of positive actions, whereas the is narcissism directly related to negative actions.

\section{NARCISSISM AS A MODERATOR IN THE LINK BETWEEN ENTITLEMENT AND ORGANIZATIONAL BEHAVIORS}

Prior to conducting moderation analyses, participants were divided into three groups, depending on their narcissism level: low (below the median score), medium (equal to the median score) and high level of narcissism (scores over the median). Narcissism moderated the relationship between passive entitlement and OCB; $B=0.28, p=.070$, change $F(3,89)=5.35$, $p=.002$. Passive entitlement was positively related to citizenship behaviors only among individuals with a high level of narcissism $(\beta=.59, t(15)=2.83$, $p=.013, R^{2}=.30$, see Figure 1$)$, and unrelated to OCB in groups with low $(\beta=.05, p=.854)$ and average $(\beta=.18, p=.155)$ levels of narcissism.

Table 1

Zero-order correlations of entitlement attitudes, narcissism, and organizational behaviors: citizenship and counterproductive $(N=100)$

\begin{tabular}{|c|c|c|c|c|c|}
\hline & CWB & Active & Passive & Revenge & Narcissism \\
\hline OCB & $-.55^{* * *}$ & $.22^{*}$ & $.28^{* *}$ & $-.29^{* *}$ & -.13 \\
\hline CWB & & $-.38^{* * *}$ & $-.31^{* * *}$ & .07 & $.30^{* * *}$ \\
\hline Active & & & $.26^{* *}$ & .10 & $.25^{* *}$ \\
\hline Passive & & & & $-.21^{*}$ & -.10 \\
\hline Revenge & & & & & .08 \\
\hline
\end{tabular}


Table 2

Hierarchical regression analyses for organizational behaviors with narcissism and entitlement attitudes as predictors

\begin{tabular}{|c|c|c|c|c|}
\hline & \multicolumn{2}{|c|}{ Organizational citizenship behaviors } & \multicolumn{2}{|c|}{ Counterproductive work behaviors } \\
\hline & $\beta$ & $\Delta R^{2}$ & $\beta$ & $\Delta R^{2}$ \\
\hline Model 1 & & .02 & & $.11^{* * *}$ \\
\hline Narcissism & -.16 & & $.34^{* * *}$ & \\
\hline Model 2 & & $.15^{* * *}$ & & $.11^{* * *}$ \\
\hline Narcissism & -.18 & & $.39^{* * *}$ & \\
\hline $\mathrm{AE}$ & $.27^{*}$ & & $-.34^{* * *}$ & \\
\hline PE & .13 & & -.08 & \\
\hline RE & $-.25^{*}$ & & .06 & \\
\hline Model 3 & & $.12^{* * *}$ & & $.17^{* * *}$ \\
\hline Narcissism & $-2.00^{* * *}$ & & $2.12^{* * *}$ & \\
\hline $\mathrm{AE}$ & -.40 & & $.82^{* *}$ & \\
\hline $\mathrm{PE}$ & -.70 & & .40 & \\
\hline $\mathrm{RE}$ & -.26 & & -.22 & \\
\hline Narcissism $\times \mathrm{AE}$ & .20 & & $-.31^{* * *}$ & \\
\hline Narcissism $\times$ BE & $.28^{\wedge}$ & & -.14 & \\
\hline Narcissism $\times$ RE & -.00 & & .08 & \\
\hline
\end{tabular}

Note. AE - active entitlement; PE - passive entitlement; RE - revenge entitlement; narcissism measured by Narcissistic Personality Inventory; ${ }^{*} p<.05,{ }^{* *} p<.01,{ }^{* * *} p<.001 ;{ }^{\wedge} p<.10$.

Including the interaction between narcissism and entitlement allowed us to predict greater variance of counterproductive organizational behaviors; $B=-.36$, $p=.001$, change $F(3,89)=10.33, p<.001$. Higher lev-

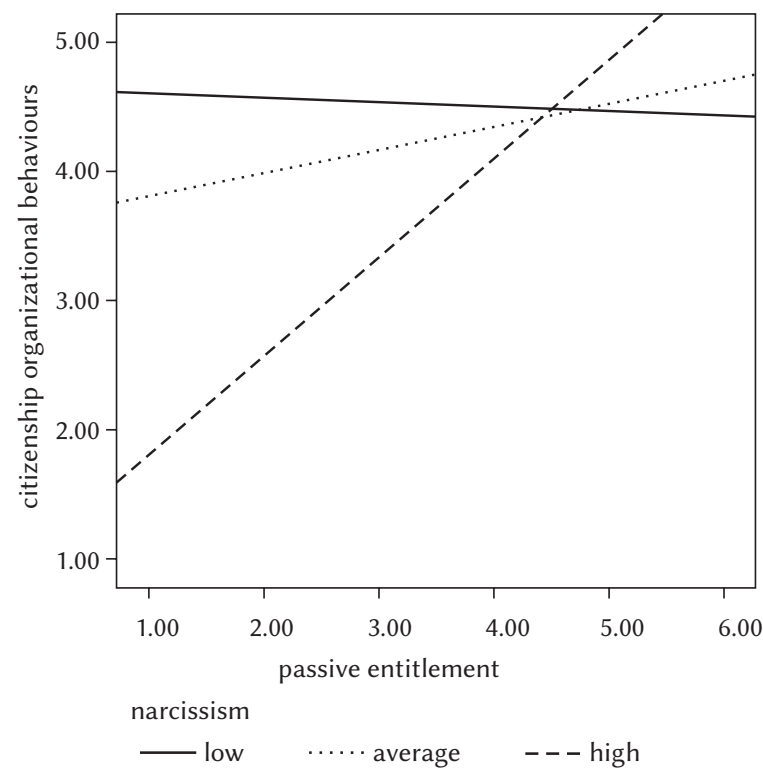

Figure 1. Simple-slope analysis for citizenship organizational behaviors predicted by passive entitlement among individuals with low (-1SD), average; and high (+1 SD) level of narcissism. els of active entitlement were associated with lower levels of counterproductive organizational behaviors among individuals with higher levels of narcissism $\left(\beta=.85, t(15)=6.12, p=.001, R^{2}=.70\right.$, see Figure 2$)$,

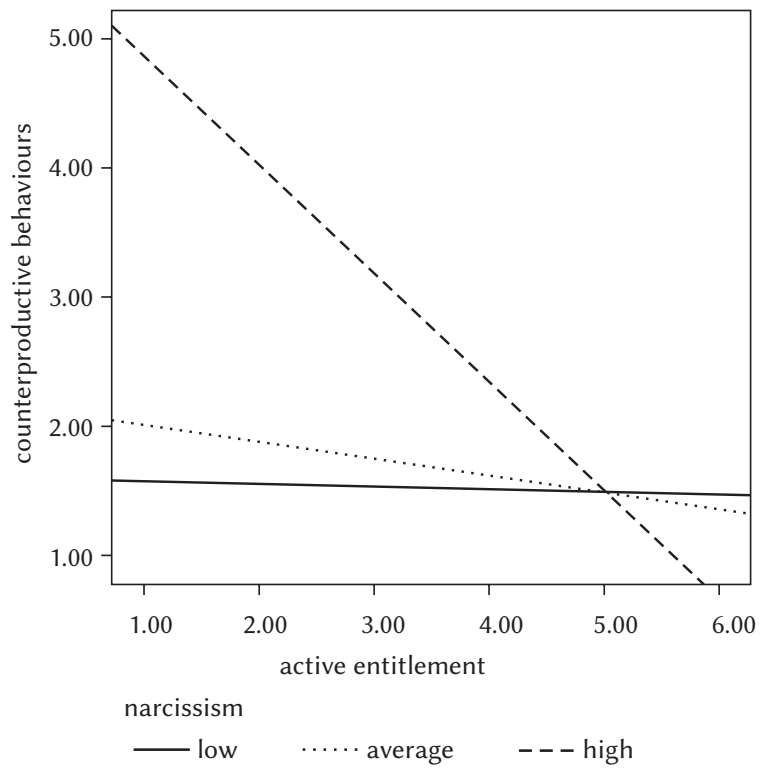

Figure 2. Simple-slope analysis for counterproductive organizational behaviors predicted by active entitlement among individuals with low $(-1 S D)$, average; and high (+1SD) level of narcissism. 
and were unrelated to $\mathrm{CWB}$ among individuals with low $(\beta=-.04, p=.872)$ and average $(\beta=-.13$, $p=.300$ ) levels of narcissism. That is, the relationship between entitlement attitudes and counterproductive organizational behaviors is present only among highly narcissistic employees.

\section{ENTITLEMENT AS A MEDIATOR BETWEEN NARCISSISM AND ORGANIZATIONAL BEHAVIORS}

To examine the role of entitlement as a mediating factor in the relationships between narcissism and organizational behaviors, the PROCESS macro for SPSS was used (Hayes, 2013). Since only active entitlement was simultaneously related to narcissism (Path A) and to OCB and COB (Path B), there was no justification for examining possible mediating effects for passive entitlement and revenge entitlement (Baron \& Kenny, 1986). We used the bootstrapping procedure since the number of cases for analyses was relatively low (lower than 200). This procedure further allows for controlling for measurement bias and provides confidence intervals for estimated error. Indirect effects are reported in Table 3.

As reported in Table 3, the indirect effect of narcissism on organizational citizenship behaviors via active entitlement was insignificant. However, the indirect effect of narcissism on counterproductive work behaviors was significant and moderate (IE $=-.39$, $S E=.08, p<.001)$. This mediation is illustrated in Figure 3. Mediational analyses revealed a suppression effect for this relationship since the regression coefficient for narcissism as a predictor of CWB was higher $(\beta=.48, p<.001)$ after including active entitlement in the predictive model in comparison to the direct relationship between narcissism and CWB $(\beta=.30, p=.002)$. Narcissism resulted in stronger CWB without active entitlement, or, in other words, CWB increased directly and decreased indirectly via active entitlement.

\section{DISCUSSION}

The current study aimed to investigate the interrelations between entitlement and organizational behaviors, notably OCB and CWB, and to relate these findings to prior studies on narcissism and organizational behaviors (Campbell et al., 2011). Entitlement was conceptualized as a dispositional variable, composed of three dimensions - active, passive and revenge entitlement - that covers a broad spectrum of entitlement attitudes (Piotrowski \& Żemojtel-Piotrowska, 2009; Żemojtel-Piotrowska et al., 2013). As Miles et al. (2002) suggested, both citizenship oriented and counterproductive organizational behaviors could be explained by factors related to affectivity and personal variables. In the current study, we examined entitlement and narcissism as important dispositional factors associated with $\mathrm{OCB}$ and CWB. Furthermore, we examined grandiose narcissism as a moderator in the relationship between entitlement and organizational behaviors and entitlement as a possible mediator of the relationship between narcissism and organizational behavior in an effort to shed light on their possible interactions as predictors of OCB and CWB.

It was hypothesized that active entitlement would be positively related to citizenship behaviors, since it is positively related to factors identified by Spector and Fox (2002), such as an internal locus of control and positive affectivity, that increase OCB. The current study confirmed this assumption, but only among individuals with high levels of narcissism.

We also assumed that passive entitlement is associated with lower levels of CWB, as this aspect of entitlement is communal (Żemojtel-Piotrowska et al., 2015a), unrelated to negative affectivity (ŻemojtelPiotrowska et al., 2013; Żemojtel-Piotrowska et al., 2015c) and unhindered agency (Żemojtel-Piotrowska et al., 2015b). This assumption was confirmed, although passive entitlement did not allow us to predict CWB over narcissism. Since this aspect of entitlement is positively related to passivity and an external locus of control and unrelated to positive affectivity, the detected positive relationship with $\mathrm{OCB}$ was weak. Moreover, passive entitlement was positively related to OCB only among individuals with high levels of narcissism.

Revenge entitlement was negatively related to OCB and unrelated to CWB, partially supporting our

\section{Table 3}

Indirect effects of narcissism on organizational behaviors, mediated through active entitlement

\begin{tabular}{lcc}
\hline & Estimate & $S E$ \\
\hline $\mathrm{NPI} \rightarrow \mathrm{AE} \rightarrow \mathrm{OCB}$ & $.069(.003 .174)$ & .046 \\
$\mathrm{NPI} \rightarrow \mathrm{AE} \rightarrow \mathrm{CWB}$ & $-.435(-.590-.279)$ & .079 \\
\hline
\end{tabular}

Note. Results obtained by bootstrapping procedure $(n=1,000)$, with $95 \%$ confidence intervals presented in parentheses. NPI narcissism; AE - active entitlement; OCB - organizational citizenship behaviors; CWB - counterproductive work behaviors.

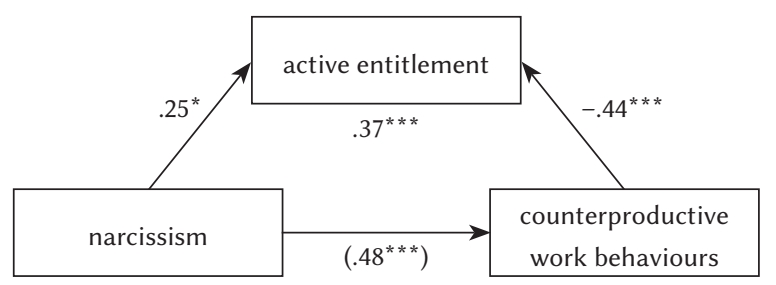

Figure 3. Active entitlement as mediator of narcissism influence on counterproductive work behaviors $\left[F(2,97)=21.77, p<.001, R^{2}\right.$ adj $\left.=.31\right]$. 
predictions. This aspect of entitlement is negative, similar to narcissistic entitlement; however, contrary to narcissism, it was not related to engagement in harmful actions toward organizations. The relationship between OCB and revenge entitlement was independent from narcissism.

Mediational analyses revealed that the positive relationship between grandiose narcissism and CWB was mediated by active entitlement. A suppression effect was detected, as narcissism directly increased CWB and decreased it indirectly via active entitlement. This finding points to the importance of active entitlement for functioning in the workplace. It seems that active entitlement could inhibit the impact of grandiose narcissism on counterproductive behaviors, probably since active entitlement is associated with more productive and constructive reactions at work.

Former studies have examined the importance of narcissism and entitlement in relation to organizational behaviors and the work context, but they have focused on negative aspects of psychological entitlement (Harvey \& Martinko, 2008; Fisk, 2010). The current study allowed for a more comprehensive examination of the significance of entitlement in predicting organizational behaviors. As psychological entitlement is often linked to narcissism in personality and social psychology, it was also important to shed light on possible interactions between both personal factors. The results of the current study indicated that positive aspects of entitlement are profitable for an organization because they are positively related to $\mathrm{OCB}$ and negatively to CWB. These relationships are observed especially among employees with high levels of narcissism. This result may be surprising, particularly because we predicted a stronger relationship between negative behaviors and entitlement in employees with higher levels of narcissism than employees with lower levels of narcissism. However, recent findings on narcissism could be useful in explaining this result. Subclinical (or grandiose) narcissism, contrary to personality disorders, is to some extent profitable for the individual since it is based on agency, a grandiose self-view and higher expectations toward others as a result of one's high self-esteem (Miller \& Campbell, 2008; Sedikides, Rudich, Gregg, Kumashiro, \& Rusbult, 2004). For this reason, highly narcissistic workers could potentially be proactive in their profession and satisfied with their lives and workplace. Since they have higher expectations toward others, such as in the case where they manifest healthy aspects of entitlement, they could be engaged in supportive actions toward their organization and less engaged in costly ones. For this reason, entitlement could be profitable for an organization if the worker, who has a grandiose self-view, manages his/her expectations toward others in a constructive form. On the other hand, among low-narcissistic workers, healthy aspects of entitlement (i.e. active and passive) are less important predictors of organizational behaviors (i.e. active entitlement is unrelated to $\mathrm{OCB}$ and passive entitlement is unrelated to CWB), and only its negative aspects (revenge) are associated with a lower level of pro-organizational actions. Contrary to narcissism, even the negative aspects of entitlement seem to be unrelated to costly, counterproductive work behaviors. Generally, these results are congruent with the findings of Bourdage and colleagues (Bourdage, Lee, Lee, \& Shin, 2009) that narcissistic employees engaged in $\mathrm{OCB}$ as a form of impression management. The results also support the suggestion by Campbell et al. (2011) that narcissistic individuals could engage in OCB when such actions could be profitable for them. This suggestion is also supported by the detected mediation of the relationship between narcissism and counterproductive work behaviors by active entitlement, which partially weakened this relationship. This means that when narcissism leads to more proactive behaviors that are associated with active entitlement, such as the overt pursuit of personal goals and defending one's rights, counterproductive work behaviors tend to be inhibited.

\section{LIMITATIONS AND FUTURE DIRECTIONS}

The current study was a cross-sectional, self-report study. For this reason, any causal interpretation is impossible. Moreover, as the negative, undesirable actions were measured via questionnaire, it is possible that actual behavior could be conditioned by different factors. Another problem is a common method bias, which is related to using self-report measures. There are several sources of this undesirable factor, including acquiescence, common scale formats, social desirability or the consistency motif (see Podsakoff, MacKenzie, Lee, \& Podsakoff, 2003). In the current study, some of the main sources of bias were avoided, since methods were rotated (to avoid a context effect), the response options varied (to avoid common scale formats), and the entitlement questionnaire was correlated with the social desirability scale and the neutral scales measuring acquiescence in the process of scale development (Piotrowski \& Żemojtel-Piotrowska, 2009). The NPI is a well-established and commonly used scale; hence its validity and reliability are well documented. However, the OCB and CWB scales could be influenced by social desirability. For this reason, the results obtained in the current study should be interpreted with caution. The detected relationships are consistent with former results, especially in regard to narcissism (Campbell et al., 2011; Penney \& Spector, 2002). To address the problem of using self-report methods, adding observational data, such as peer-rankings completed by co-workers or supervisors, is recommended. Also, the number of participants in the current study was rela- 
tively small, and they were generally well-educated, and mostly employed in the public sector. For this reason, generalization of the findings is difficult.

The current study adds to earlier research by offering a more comprehensive examination of the entitlement phenomenon. As such, some unexpected, positive analyses of this variable for organizational behaviors were identified. Additionally, the current research indicates the importance of the interaction between narcissism and entitlement, and supports the assumption that psychological entitlement brings a unique, incremental contribution (beyond narcissism alone) to our knowledge about the sources of organizational behaviors.

In future studies, longitudinal data should be collected to further examine the role of psychological entitlement as a possible predictor of organizational behaviors. Moreover, the current study does not offer an explanation for the way in which psychological mechanisms could be responsible for the positive relationships between active and passive entitlement and citizenship organizational behaviors. Since active and passive entitlement are related to distinct motivations (Żemojtel-Piotrowska et al., 2015b), these mechanisms could be different and merit exploration. The most likely mediating variables for active entitlement include higher self-esteem and agency and positive identification with the organization for passive entitlement.

\section{References}

Ackerman, R., \& Donnellan, M. B. (2013). Evaluating self-report measures of narcissistic entitlement. Journal of Psychopathology \& Behavioral Assessment, 35, 460-474. DOI: 10.1007/s10862-013-9352-7

Adams, J. S. (1963). Towards an understanding of inequality. Journal of Abnormal and Normal Social Psychology, 67, 422-436.

Baron, R. M., \& Kenny, D. A. (1986). The moderatormediator variable distinction in social psychological research: Conceptual, strategic and statistical considerations. Journal of Personality and Social Psychology, 51, 1173-1182.

Bazińska, R., \& Drat-Ruszczak, K. (2000). Struktura narcyzmu w polskiej adaptacji kwestionariusza NPI Ruskina i Hulla [Structure of narcissim in Polish adaptation of NPI by Raskin \& Hull]. Czasopismo Psychologiczne, 6, 171-187.

Bishop, J., \& Lane, R. C. (2002). The dynamics and dangers of entitlement. Psychoanalytic Psychology, 19, 739-758. DOI: 10.1037//0736-9735.19.4.739

Blakely, G. L., Andrews, M. C., \& Moorman, R. H. (2005). The moderating effects of equity sensitivity on the relationship between organizational justice and organizational citizenship behaviors. Journal of Business and Psychology, 20, 259-273. DOI: $10.1007 / \mathrm{s} 10869-005-8263-3$
Bourdage, J. S., Lee, J.-H., Lee, K., \& Shin, K.-H. (2009). Good soldiers versus good actors: An investigation of OCB motives. Paper presented at the annual meeting of the Society for Industrial and Organizational Psychology. New Orleans, Louisiana.

Byrne, Z. S., Miller, B. K., \& Pits, V. E. (2010). Trait entitlement and perceived favorability of human resource management practices in the prediction of job satisfaction. Journal of Business and Psychology, 25, 451-464. DOI: 10.1007/s10869-009-9143-z

Campbell, K.W., Bonacci, A. M., Shelton, J., Exline, J. J., \& Bushman, B. J. (2004). Psychological entitlement: Interpersonal consequences and validation of self-report measure. Journal of Personality Assessment, 83, 29-45.

Campbell, K. W., Hoffman, B. J., Campbell, S. M., \& Marchisio, G. (2011). Narcissism in organizational contexts. Human Resource Management Review, 21, 268-284. DOI: 10.1016/j.hrmr.2010.10.007

Cole, G. A. (1995). Organisational behavior: Theory and practice. London: D. P. Publications.

Czarnota-Bojarska, J. (2011). Zachowania obywatelskie w organizacji - próba konstrukcji narzędzia pomiaru [Citizenhip behaviors in organization the attempt of construction of measurement tool]. In: J. Czarnota-Bojarska, \& I. Zinserling (eds.), W kręgu psychologii spotecznej (pp. 145-157). Warszawa: University of Warsaw Press.

Czarnota-Bojarska, J. (2012). Counterproductive work behaviors and satisfaction with work: A not so simple relations as it seems to be. Oral presentation at IX Meeting of Polish Society of Social Psychology, Sopot 12-14 September 2012.

Desmarais, S., \& Curtis, J. (1997). Gender and perceived pay entitlement: Testing for effects of experience with income. Journal of Personality and Social Psychology, 72, 141-150.

Exline, J. J., \& Zell, A. L. (2009). Empathy, self-affirmation, and forgiveness: The moderate roles of gender and entitlement. Journal of Social and Clinical Psychology, 28, 1071-1099. DOI: 10521/ jscp.2009.28.09.1071

Feather, N. T. (2003). Distinguishing between deservingness and entitlement: Earned outcomes versus lawful outcomes. European Journal of Social Psychology, 33, 367-385. DOI: 10.1002/ejsp. 152

Fisk, G. M. (2010). "I want it all and I want it now!" An examination of the etiology, expression, and escalation of excessive employee entitlement. Human Resource Management Review, 20, 102-114. DOI: 10.1016/j.hrmr.2009.11.001

Fox, S., Spector, P. E., Goh, A., Bruursema, K., \& Kessler, S. R. (2012). The deviant citizen: Measuring potential positive relations between counterproductive work behavior and organizational citizenship behavior. Journal of Occupational and Organizational Psychology, 85, 199-220. 
Fox, S., Spector, P. E., \& Miles, D. (2001). Counterproductive work behavior (CWB) in response to job stressors and organizational justice: Some mediator and moderator tests for autonomy and emotions. Journal of Vocational Behavior, 59, 291-309.

Harvey, P., \& Martinko, M. J. (2009). An empirical examination of the role of attributions in psychological entitlement and its outcomes. Journal of Organizational Behavior, 30, 459-476.

Hayes, A. F. (2013). Introduction to mediation, moderation and conditional process analysis. A regression-based approach. New York: The Guilford Press.

Huseman, R. C., Hatfield, J. D., \& Miles, E. W. (1987). A new perspective on equity theory: The equity sensitivity construct. Academy of Management Review, 12, 222-234.

Klicperova, M., Feierabend, I. K., \& Hofstetter, C. R. (1997). In the search for a post-communist syndrome: A theoretical framework and empirical assessment. Journal of Community and Applied Social Psychology, 7, 39-52.

Koralewicz, J., \& Ziółkowski, M. (1991). The Polish mentality of the late 80 s. Polish Western Affairs, 91, 109-121.

Lessard, J., Greenberger, E., Chen, C., \& Farruggia, S. (2011). Are youth feelings of entitlement always 'bad'? Evidence for a distinction between exploitive and non-exploitive dimensions of entitlement. Journal of Adolescence, 34, 521-529.

Major, B., McFarlin, D., \& Gagnon, D. (1984). Overworked and underpaid: On the nature of gender differences in personal entitlement. Journal of Personality and Social Psychology, 47, 1399-1412.

Miller, J. D., \& Campbell, W. K. (2008). Comparing clinical and social-personality conceptualizations of narcissism. Journal of Personality, 76, 449-476.

Miles, D. E., Borman, W. E., Spector, P. E., \& Fox, S. (2002). Building an integrative model of extra role behaviors: A comparison of counterproductive work behavior with organizational work behavior. International Journal of Selection and Assessment, 10, 51-57.

Naumann, S. E., Minsky, B. D., \& Sturman, M. C. (2002). The use of the concept "entitlement" in management literature: A historical review, synthesis, and discussion of compensation policy implications. Human Resource Management Review, 12, 145-166.

Organ, D. W. (1997). Organizational Citizenship Behavior: It's construct clean-up time. Human Performance, 10, 85-98.

Organ, D. W. (1988). Organizational citizenship behavior: The good soldier syndrome. Lexington, MA: Lexington Books.

Pelham, B. W., \& Hetts, J. J. (2001). Underworked and overpaid: evaluated entitlement in men' selfpay. Journal of Experimental Social Psychology, 37, 93-103.
Penney, L. M., \& Spector, P. E. (2002). Narcissism and counterproductive work behavior: Do bigger egos mean bigger problems? International Journal of Selection and Assessment, 10, 126-134.

Piotrowski, J., \& Żemojtel-Piotrowska, M. (2009). Kwestionariusz roszczeniowości [Entitlement questionnaire]. Roczniki Psychologiczne, 12, 151-177.

Podsakoff, P. M., Mackenzie, S. B., Paine, J. B., \& Bachrach, D. G. (2000). Organizational citizenship behaviors: A critical review of the theoretical and empirical literature and suggestions for future research. Journal of Management, 26, 513-563.

Podsakoff, P. M., Mackenzie, S. B., Lee, J. Y., \& Podsakoff, N. P. (2003). Common method biases in behavioral research: A critical review of the literature and recommended remedies. Journal of Applied Psychology, 88, 879-903. DOI: 10.1037/00219010.88.5.879

Podsakoff, N. P., Whiting, S. W., Podsakoff, P. M., \& Blume, B. D. (2009). Individual- and organizational-level consequences of organizational citizenship behaviors: A meta-analysis. Journal of Applied Psychology, 94, 122-141.

Pryor, L. R., Miller, J. D., \& Gaughan, E. T. (2008). A comparison of the Psychological Entitlement Scale and the Narcissistic Personality Inventory's Entitlement Scale: relations with general personality traits and personality disorders. Journal of Personality Assessment, 90, 517-520. DOI: 10.1080/00223890802248893

Raskin, R., \& Terry, H. (1988). A principal-components analysis of the Narcissistic Personality Inventory and further evidence of its construct validity. Journal of Personality and Social Psychology, 54, 890-902.

Rothman, A. M. (2012). Adolescent attachment and entitlement in a world of wealth. Journal of Infant, Child, and Adolescent Psychotherapy, 11, 53-65. DOI: 10.1080/15289168.2012.650002

Sedikides, C., Rudich, E. A., Gregg, A.P., Kumashiro, M., \& Rusbult, C. (2004). Are normal narcissists psychologically healthy? Self-esteem matters. Journal of Personality and Social Psychology, 87, 400-416.

Spector, P. E. (2011). The relationship of personality to counterproductive work behavior (CWB): An integration of perspectives. Human Resource Management Review, 21, 342-352. DOI: 10.1016/j. hrmr.2010.10.002

Spector, P. E., \& Fox, S. (2002). An emotion-centred model of voluntary work behavior: Some parallels between counterproductive work behavior (CWB) and organizational citizenship behavior (OCB). Human Resource Management Review, 12, 269-292.

Tomlinson, E. C. (2013). An integrative model of entitlement beliefs. Employee Responsibility and Rights Journal, 25, 67-87. DOI 10.1007/s 10672-012-9208-4 
Twenge, J., \& Campbell, W. K. (2009). The narcissism epidemic. Life in the age of entitlement. New York: Free Press.

Żemojtel-Piotrowska, M., Baran, T., Clinton, A., Piotrowski, J., Baltatescu, S., \& Van Hiel, A. (2013). Materialism, subjective well-being, and entitlement. Journal of Social Research and Policy, 4, 79-91.

Żemojtel-Piotrowska, M., \& Piotrowski, J. (2011). Temperamentalne i osobowościowe wyznaczniki postaw roszczeniowych [Temperamental and personality conditionals of entitlement attitudes]. Polskie Forum Psychologiczne, 16, 159-177.

Żemojtel-Piotrowska, M., Piotrowski, J., \& Baran, T. (2011). Postawy roszczeniowe a system wartości w ujęciu Shaloma Schwartza [Entitlement attitudes and Schwartz's values system]. Psychologia Spoteczna, 17, 146-158.

Żemojtel-Piotrowska, M., Piotrowski, J., Cieciuch, J., Calogero, R., Van Hiel, A., Argentero, P., Baltatescu, S., Baran, T., Bardhwaj, G., Bukowski, M., Chargazia, M., Clinton, A., Halik, M. H., Ilisko, D., Khachatryan, N., Klicperova-Baker, M., Kostal, J., Kovacs, M., Letovancova, E., Liik, K., Marganski, A., Michałowski, J., Nord, I., Paspalanova, E., Perez de Leon, P., Techera, J., Rojas, M., Różycka-Tran, J., Sawicka, A., Seibt, B., Semkiv, I., Tiliouine, H., Ha Khanh, T. T., van den Bos, K., \& Wills-Herrera, E. (2015a). Measurement of psychological entitlement in 28 countries. European Journal of Psychological Assessment (in press). DOI: 10.1027/10155759/a000286

Żemojtel-Piotrowska, M., Piotrowski, J., \& Clinton, A. (2015b). Agency, communion and three forms of entitlement. International Journal of Psychology. Advance online publication. DOI: 10.1002/ ijop. 12140

Żemojtel-Piotrowska, M., Piotrowski, J., Clinton, A., Cieciuch, J., Różycka-Tran, J., \& Truong, T. K. H. (2015c). Entitlement and subjective well-being: Three nations study. Health Psychology Report, 3, 141-149. DOI: 10.5114/hpr.2015.49635 